\title{
The Efforts of Attorney Offices to Resolve Criminal Cases Based on the Concept of Restorative Justice
}

\author{
Joko Sriwidodo \\ Universitas Jayabaya Jakarta \\ email correspondence:joko sriwidodo@jayabaya.ac.id
}

\begin{abstract}
Recently, several cases show the criminal justice system in Indonesia has not guaranteed legal certainty and justice for the people. Thus, it is necessary to have a breakthrough in Indonesia's criminal justice system by using the restorative justice approach. This approach is carried out by transferring and institutionalizing in accordance with justice. For this reason, it is necessary to have a specific regulation regarding the settlement of cases based on the concept of restorative justice in law enforcement institutions in Indonesia, especially in the attorney offices. The problems in this research are: How is law enforcement in Indonesia based on the concept of restorative justice? And how are the attorney's efforts to resolve criminal cases based on the concept of restorative justice? This study aims to provide an overview of the restorative justice application. To respond to the senses of justice in society by implementing case resolution based on restorative justice. This normative legal research is conducted by library research through studying and analyzing primary, secondary, and tertiary legal materials. The research results show that the resolve of criminal cases by the Attorney General Office uses the Indonesian Attorney Office Regulation (PERJA) Number 15 of 2020 concerning Cessation of Prosecution Based on Restorative Justice.
\end{abstract}

Keywords: Restorative Justice; Attorney; Dispute Settlement.

Date of Submission: January 02, 2021

Date of Publication: May 10, 2021

DOI: http://dx.doi.org/10.33096/substantivejustice.v4i1.121

\section{INTRODUCTION}

Criminal act as regulated in Article 104-488 Chapter II Indonesia Criminal Code or KUHP concerning the crimes, ${ }^{1}$ and article 351-358 Chapter XX concerning persecution. ${ }^{2}$ At this time, the thoughts and studies renewal in criminal law is necessary to anticipate the development of life in society, which also encourages new criminal acts. Even in these developments, the direction of these problems often hits legal theories studied by the

1 Hattu, Jacob. (2020). Pertanggungjawaban Pidana Pengambilan Jenasah Covid-19 Secara Paksa Berdasarkan Aturan Tindak Pidana Umum dan Tindak Pidana Khusus. Jurnal Belo, 6(1), pp. 11-32, p, 19

2 Ishaq, Abdul Razak. (2019). Sanksi Penganiayaan Dalam Hukum Pidana Adat Kerinci dan Hukum Pidana Indonesia. Al-Risalah Forum Kajian Hukum dan Sosial Kemasyarakatan, 19(1), pp. 17-36, p. 23, https://doi.org/10.30631/al-risalah.v19i1.147

This work is licensed under a Creative Commons Attribution 4.0 International License. 
previous law scholars. Thus, it is necessary to provide an operational definition and the function of criminal law in a comprehensive and up-to-date manner to respond to the evolution and developments in criminal behavior. Criminal law functions are protecting legal interests, individual interests, and the interests of society and the State. ${ }^{3}$ Simply to said that criminal act is the action which perpetrator can be subject to punish. ${ }^{4}$ The criminal act or what Moeljatno said is referred to as the nature of the act, namely the nature of being prohibited by punishment if it is violated. ${ }^{5}$ Criminal action, by Moeljatno's point of view, is the perpetrator element, and matters relating to it, such as mistakes and taking responsibility, cannot be included in the definition of a criminal act, but this element is part of the element of criminal responsibility. ${ }^{6}$

There are two basic concepts in the structure of a criminal act: a concept that unites the aspects that make up a criminal act, namely action, and accountability. Then the concept that separates the terms of the criminal offender is a criminal offense and criminal responsibility. ${ }^{7}$ In its practical development, criminal law has also experienced significant developments, one of which is the birth of the concept of restorative justice. ${ }^{8}$ Restorative justice is a settlement process for actors who are involved in a certain criminal act jointly seeking solutions in dealing with the cases after the criminal act and dealing with how to overcome the implications of that criminal act in the future. ${ }^{9}$

The concept of punishment continues to develop starting from the rise of traditional justice theories such as retributive justice to the emergence of modern justice theories such as restorative justice in solving criminal problems. ${ }^{10}$ Restorative justice is a theory that emphasizes the recovery of losses due to a criminal act. ${ }^{11}$

${ }^{3}$ Saraswati, Putu Sekarwangi. (2015). Fungsi Pidana Dalam Menanggulangi Kejahatan. Jurnal Advokasi, 5 (2), pp. 139-154, p.146.

${ }^{4}$ Mukhlis, R. (2012). Tindak Pidana Di Bidang Pertanahan Di Kota Pekanbaru. Jurnal Ilmu Hukum, 4(1), 203-204.

${ }^{5}$ Hakim, L. (2019). Implementasi Teori Dualistis Hukum Pidana Di Dalam Rancangan Kitab UndangUndang Hukum Pidana (RKUHP). Jurnal Krtha Bhayangkara, 13(1), pp. 1-19, p. 4, https://doi.org/10.31599//krtha.v13i1.12

${ }^{6}$ Saputra, R. P. (2019). Perkembangan Tindak Pidana Pencurian Di Indonesia. Jurnal Pahlawan Volume. 2(2), pp. 1-8, p. 1 p. 59

Maramis, F. (2013). Hukum Pidana Umum dan Tertulis di Indonesia. Jakarta: Raja Grafindo Persada,

${ }^{8}$ Wagiu, J. D. (2015). Tinjauan Yuridis Terhadap Asas Keadilan Restoratif dalam Perkara Tindak Pidana Penggelapan. Lex Crimen, 4(1). pp. 57-70, p. 57

9 Laksana, Andri Winjaya. (2017). "Keadilan Restoratif Dalam Penyelesaian Perkara Anak Yang Berhadapan Dengan Hukum Dalam Sistem Peradilan Pidana Anak", Jurnal Pembaharuan Hukum, 4(1), pp. 5764, 58, http://dx.doi.org/10.26532/jph.v4i1.1644 Look at to in Sriwidodo, Joko. (2014). Penerapan Mediasi Tindak Pidana Kekerasan Dalam Rumah Tangga Berdasarkan Restorative Justice Dalam Sistem Peradilan Pidana di Indonesia. Yogyakarta: Kepel Press, p. 41.

${ }^{10}$ Kurnia, P, et.al. (2015). Penegakan Hukum Melalui Restorative Justice Yang Ideal Sebagai Upaya Perlindungan Saksi Dan Korban. GEMA, 27(49), pp. 1497-1508, p.1498.

${ }_{11}$ Muladi. (2005). Hak Asasi Manusia: Hakekat, Konsep dan Implikasinya Dalam Perspektif Hukum dan Masyarakat, Bandung: Refika Aditama. 
Recently, there have been many cases in Indonesia that show the criminal justice system has not guaranteed legal certainty and justice for the community. ${ }^{12}$ The majority opinion states that Indonesian law is often sharp downward and blunt upward. This statement means that the effectiveness of law enforcement only applies to small communities that commit minor crimes. Meanwhile, perpetrators of major crimes such as corruption, collusion, and nepotism (KKN) are untouchable. ${ }^{13}$ It is as happened by Busrin or Karyo, 58 years old from Probolinggo, East Java, who was imprisoned for two years, with a fine of Rp. 2 billion for cutting mangrove trees to use as firewood. This case attracted the public's attention and the media, who considered this sentence too heavy, considering that the perpetrators were only poor people. ${ }^{14}$

The Indonesian criminal justice system is still far from what the Indonesian people expect, especially in upholding the values of justice. So it is necessary to increase respect for human rights in the criminal justice system to protect human rights. ${ }^{15}$ Thus, it is necessary to have a breakthrough in Indonesia's criminal justice system using the restorative justice approach. ${ }^{16}$ This approach is carried out by transferring and institutionalizing it to accommodate justice. ${ }^{17}$

The establishment of the Attorney General's Office Regulation or PERJA of the Republic of Indonesia Number 15 of 2020 concerning Cessation of Prosecutions based on Restorative Justice gives more hope for creating justice in this country, especially the hopes of the community to achieve a greater sense of justice. PERJA Number 15 of 2020 also established when the world was in a pandemic, many people were desperate for their lives, and many of them took shortcuts for their survival. So that during this pandemic, crime and criminal acts increased significantly. Therefore, it is hoped that the implementation of the restorative approach by PERJA of the Republic of Indonesia Number 15 of 2020 can reduce prison prisoners and fulfillment of simple, fast and low-cost judicial principles. Based on this background, this research will discuss how is the law enforcement in Indonesia based on the concept of restorative justice? And how are the efforts of the attorney's office to resolve criminal cases according to restorative justice? In this study, the researcher wants to try to provide an overview of the application of restorative justice.

${ }^{12}$ Taufiq, M. (2013). Penyelesaian Perkara Pidana Yang Berkeadilan Substansial. Yustisia, 2(1), pp. 25-32, p. 35, https://doi.org/10.20961/yustisia.v2i1.11058

${ }_{13}$ Biroli, A. (2015). Problematika Penegakan Hukum Di Indonesia (Kajian Dengan Perspektif Sosiologi Hukum). Dimensi Journal of Sociology, 8 (2), pp. 1-9, p. 1

${ }^{14}$ Sholahudin, U. (2018). Keadilan Hukum Bagi Si Miskin; Sebuah Elegi Si Miskin Dihadapan Tirani Hukum. Journal of Urban Sociology, 1 (1), pp. 35-45, https://doi.org/10.30742/jus.v1i1.562

${ }^{15}$ Siregar, R. E. (2015). Due Process Of Law Dalam Sistem Peradilan Pidana Di Indonesia Kaitannya Dengan Perlindungan HAM. FITRAH, 1 (1), pp. 35-46, p. 45, https://doi.org/10.24952/fitrah.v1i1.326

${ }^{16}$ Kristian, C. T. (2015). Penyelesaian Perkara Pidana Dengan Konsep Keadilan Restoratif (Restorative Justice) Dalam Sistem Peradilan Pidana Terpadu Di Indonesia. Jurnal Mimbar Justitia, 1 (2), pp. 592-607, p. 592, https://doi.org/10.35194/ihmi.v1i2.42

17 Hartono, B. (2016). Analisis Keadilan Restoratif (Restorative Justice) Dalam Konteks Ultimum Remedium Sebagai Penyelesaian Permasalahan Tindak Pidana Anak. Pranata Hukum, 10 (2), pp. 86-98, p. 92. 


\section{METHOD}

This study uses a descriptive normative legal research method with normative case studies based on the statutory and case approaches. ${ }^{18}$ This research was carried out through library research by conducting studies and analyzing primary, secondary, and tertiary legal materials. This research aims to answer the sense of justice in society by implementing case settlement based on the restorative justice concept.

\section{ANALYSIS AND DISCUSSION}

\section{A. The Law Enforcement in Indonesia Based on Restorative Justice Concept}

As time goes by, the number of cases with all their forms and variations that go to court is increasing day by day, the criminal rate during the implementation of large-scale social restriction status due to the Corona or Covid-19 virus pandemic in Indonesia has increased. This figure has reached an 11 percent statistic criminal rate. ${ }^{19}$ These consequences become a burden on the court in examining and deciding cases according to the principle of "simple, fast and low-cost justice" without sacrificing the achievement of judicial objectives, namely legal certainty, benefit, and justice. ${ }^{20}$ However, the settlement of criminal acts through courts or penals has received sharp criticism from practitioners and legal theorists. The role and function of the judiciary are currently considered too heavy (overloaded), slow and waste of time, very expensive and less responsive to public interests, or is considered too formalistic and too technical), especially the existence of a "judicial mafia" which seems to indicate that a judgment can be bought. ${ }^{21}$

Indonesian law enforcement is failed in achieving the objectives contained in the law. Therefore, alternative law enforcement emerged, namely the Restorative Justice System, where the approach used is sociocultural and not normative. ${ }^{22}$ Restorative justice is a theory of justice that has an emphasis on repairing losses caused by criminal behavior. This is done by bringing together both the perpetrator and the victim to decide the best way to solve the existing case. The Restorative justice approach focuses on the needs of both

${ }^{18}$ Marzuki, Peter Mahmud. (2008). Penelitian Hukum. Cet2. Jakarta: Kencana, p. 29

19 Anwar, Mohamad. (2020). Asimilasi dan Peningkatan Kriminalitas Di Tengah Pembatasan Sosial Berskala Besar Pandemi Corona. ADALAH: Buletin Hukum dan Keadilan, 4(1), pp. 101-106, p. 102, https://doi.org/10.15408/adalah.v4i1.15504

${ }^{20}$ Ariefianto, Y. (2016). Penerapan Restoratif Justice Dalam Penyelesaian Kasus Kecelakaan Lalu Lintas. Kumpulan Jurnal Mahasiswa Fakultas Hukum. 1(1), pp. 1-26, p.4

${ }^{21}$ Sutiyoso, Bambang. (2006). Penyelesaian Sengketa Bisnis, Solusi Dan Antisipasi Bagi Peminat Bisnis Dalam Menghadapi Sengketa Kini dan Mendatang. Yogyakarta: Citra Media, p. 30.

${ }^{22}$ Arief; Hanafi, Ningrum Ambarsari. (2018). Penerapan Prinsip Restorative Justice Dalam Sistem Peradilan Pidana Di Indonesia. Al'Adl, 10(2), pp. 173-190, p.176, http://dx.doi.org/10.31602/al-adl.v10i2.1362 
victims and perpetrators of crime. Also, the Restorative Justice approach helps criminals to avoid other crimes in the future. ${ }^{23}$

Restorative justice emphasizes the importance of victims and community members' role in encouraging perpetrators to be responsible to the victims, restore emotional and material losses to victims, encourage dialogue or negotiations to resolve problems that have occurred to save communities from prolonged conflict. ${ }^{24}$ To produce restorative justice, which is a process in which all parties involved in a certain criminal act mutually solve the problem of dealing with the consequences in the future. The principles of restorative justice differ from conventional justice models, namely: 25

1. Make the offender responsible for restoring the losses caused by his mistake;

2. Provide an opportunity for the offender to prove his capacity and quality as well as overcome his guilt constructively;

3. Involving victims, parents, families, schools, and peers;

4. Organizing a forum to work together in solving problems;

5. Establish a direct and real relationship between mistakes and formal social reactions.

Law enforcement in Indonesia has used the settlement of restorative justice, particularly in traffic accidents. The cases were solved by bringing together perpetratorsvictims and the family to resolve the dispute in the local police presence. ${ }^{26}$ In other cases, the restorative justice settlement is used in cases of fraud committed by the Police. ${ }^{27}$ However, the settlement of restorative justice in criminal cases committed by children is performed by the prosecutor. Meanwhile, in some cases involving children, the Attorney General's Office applied restorative justice through diversion.28,29 The Attorney General's Office issued several strategic policies related to the handling of children in conflict with the law, including by issuing a Regulation of the Attorney General of the Republic of Indonesia Number: PER -006 / A / JA / 04/2015 concerning Guidelines for Implementing Diversion at

${ }^{23}$ Nurwianti, Annis Gunarto, Sri Endah Wahyuningsih. (2017). Implementasi Restoratif/ Restorative Justice Dalam Penyelesaian Tindak Pidana Kecelakaan Lalu Lintas yang Dilakukan Oleh Anak di Polres Rembang. Jurnal Hukum Khaira Ummah, 12 (4), pp. 705-716, p. 709

${ }^{24}$ Satria, Hariman. (2018). Restorative Justice: Paradigma Baru Peradilan Pidana. Jurnal Media Hukum, 25(1), pp. 111-123, 117, https://doi.org/10.18196/jmh.2018.0107.111-123

${ }^{25}$ Angkasa, Hanadi, Saryono, Muhammad Budi Setyadi. (2009). Model Peradilan Restoratif Dalam Sistem Peradilan Anak (Kajian tentang Praktik Mediasi Pelaku dan Korban dalam Proses Peradilan Anak di Wilayah Hukum Balai Pemasyarakatan Purwokerto). Jurnal Dinamika Hukum, 9(3), pp. 186-204, p, 188, https://dx.doi.org/10.20884/1.jdh.2009.9.3.230

${ }^{26}$ Ariefianto, Y. Op.Cit., 22

${ }^{27}$ Apriyanto, Edwin. (2016). Penerapan Restorative Justice Sebagai Bentuk Diskresi Kepolisian Dalam Penyelesaian Perkara Tindak Pidana Penipuan di Polrestabes Semarang. Jurnal Spektrum Hukum, 13(1), pp. 55-72, p. 72, http://dx.doi.org/10.35973/sh.v13i1.1139

${ }_{28}$ Harve, R., Marlina, M., Ekaputra, M., \& Ikhsan, E. (2016). Penerapan Diversi pada Tingkat Penuntut Umum terhadap Anak sebagai Pelaku Tindak Pidana Menurut UU No 11 Tahun 2012 (Studi Kasus di Cabang Kejaksaan Negeri Padangsidimpuan di Sibuhuan). USU Law Journal, 4(3), 198-207, p. 202

${ }^{29}$ Firdaus, A. (2018-July). The Criminal Responsibility on the Under Age Children Exploitation in Indonesia [Proceedings of the 1st International Conference on Indonesian Legal Studies (ICILS 2018)]. Advances in Social Science, Education and Humanities Research, volume 192, Atlantis Press. pp, 79-82. p. 81, https://doi.org/10.2991/icils-18.2018.15 
the Level of Prosecution, conducting education and training. ${ }^{30}$ One example of a child case that was resolved through the restorative justice approach has been implemented in the Aceh region, which was carried out deliberately through the Gampong level customary court. ${ }^{31}$

Law enforcement through restorative justice settlement can be applied in Indonesia, this is stated that Restorative justice can be carried out in concreto criminal law enforcement with programs, among others, as follows. First, through the authority of the LPSK, or prosecutors and judges in court based on the provisions of Law no. 13 of 2006 and PP. 44 of 2008, but from the beginning, the approach used was the restorative justice process; second, using secondary rules that give authority to legal officers (police, prosecutors and judges) to create, extend, and change primary rules, that creation, extinction, or alteration with the restorative justice process. ${ }^{32,33}$ So from this statement, it is clear that the Attorney General's Office can take a role in law enforcement based on the concept of restorative justice.

\section{B. The Efforts of Attorney's Office To Resolve Criminal Cases According To Restorative Justice}

The criminal act is increasingly developing in line with the development of science and technology. It has developed and reaches new models, such as cybercrime which is specifically regulated in Law Number 19 of 2016 concerning Electronic Information and Transactions (ITE), with this Law many people are being prosecuted for spreading false news, inciting, provoking, or delivering hate speech. In these developments, so many people are being tried and held responsible for the law. The settlement effort does not have to go through a trial in court because if it is resolved through a trial process, there will be an accumulation of cases and overcapacity in the prison because of the large number of people that went to jail.

Accumulation of cases can occur because of the many criminal acts, especially during this pandemic where life becomes more difficult, and activities are limited so that many people try to take shortcuts. During this pandemic, crime is increasing everywhere, and

30 Kristyanto, G. H. (2018). Fungsi Kejaksaan Dalam Mewujudkan Restorative Justice Dalam Penanganan Anak Berhadapan Dengan Hukum Di Indonesia. Jurnal Surya Kencana Dua: Dinamika Masalah Hukum dan Keadilan, 5(1), pp. 459-481, p. 478, http://dx.doi.org/10.32493/SKD.v5i1.y2018.1543

${ }^{31}$ Amdani, Y. (2016). Konsep Restorative Justice dalam Penyelesaian Perkara Tindak Pidana Pencurian oleh Anak Berbasis Hukum Islam dan Adat Aceh. AL-'ADALAH, 13(1), pp. 61-76, p, 61, https://doi.org/10.24042/adalah.v13i1.1130

${ }^{32}$ Prayitno, K. (2012). Restorative Justice Untuk Peradilan di Indonesia (Perspektif Yuridis Filosofis dalam Penegakan Hukum In Concreto). Jurnal Dinamika Hukum, 12 (3), 407-420, p. 419, http://dx.doi.org/10.20884/1.jdh.2012.12.3.116

${ }^{33}$ Patricia Erickson (2003). Critical justice consciousness: Social injustice and the Criminal Justice System, Contemporary Justice Review, 6(4), 341-346, p. 345. https://doi.org/10.1080/1028258032000144785 
domestic violence has increased dramatically. ${ }^{34}$ An increase in crime or criminal acts requires legal means that can embrace and correct the perpetrators, both during the trial and after trial (when returning to society).

The Attorney General's Office of the Republic of Indonesia is a government institution that exercises state power in the field of prosecution. It must be able to give legal certainty, legal order, justice, and truth based on law and heed religious norms, decency, and morality, and must explore human values, law, and justice which live in society. ${ }^{35}$ In 2020 the Attorney General's Office of the Republic of Indonesia had issued a new regulation, namely the Indonesian Attorney's Office Regulation (PERJA) Number 15 of 2020 concerning Cessation of Prosecution Based on Restorative Justice. With the issuance of the Attorney General's Office Regulation or PERJA Number 15 of 2020 concerning Cessation of Prosecutions based on Restorative Justice, in response to the public's wishes in general who wish to fulfill a sense of justice. PERJA Number 15 of 2020 is the spearhead of creating a sense of justice in people's lives. The perpetrators of criminal acts are required to improve the situation as before. ${ }^{36,37}$

According to Perja No. 15 on 2020, the process of resolving criminal cases is carried out through settlement of cases outside the court as stated in Article 3 paragraph (3) letter b: "there has been a restoration of the previous circumstances by restorative justice approach". The perpetrator of a criminal act must be able to restore the situation as before, especially with the victim who is most affected psychologically because of the perpetrator's violent behavior. Settlement of cases outside the court is taken, considering that social restrictions are being carried out and gathering is prohibited because of this pandemic era. Then the settlement of cases outside the court becomes more effective and right on target. Moreover, it is based on the application of restorative justice.

Application of Perja No. 15 of 2020 into criminal cases, it is hoped that it will be able to provide awareness and repentance for the perpetrators of criminal acts to stop committing these acts and restore the situation to the original both for the victim and the community in which he is located. A criminal case can be closed by law, and the prosecution is terminated based on restorative justice if the following conditions are met: 38

1. The perpetrator has committed a criminal act for the first time;

${ }^{34}$ Millah, I. A. (2020). Penanggulangan Kejahatan Di Masa Pandemi Covid-19 (Dalam Perspektif Kriminologi Dan Viktimologi). Jurnal Komunikasi Hukum (JKH), 6 (2), pp. 497-513, p. 497, https://dx.doi.org/10.23887/jkh.v6i2.28099

${ }^{35}$ Rosita, D. (2018). Kedudukan Kejaksaan Sebagai Pelaksana Kekuasaan Negara Di Bidang Penuntutan Dalam Struktur Ketatanegaraan Indonesia. Ius Constituendum. 3(1), pp. 27-47, p. 28. http://dx.doi.org/10.26623/jic.v3i1.862

${ }^{36}$ Lazuardi, G. (2020). Pendekatan Restorative Justice Dalam Tindak Pelaku Penyebaran Hoaks. Jurnal Kertha Semaya, 8 (9), pp. 1301-1312, p, 1310. https://doi.org/10.24843/KS.2020.v08.i09.p01

${ }_{37}$ Clarke, R. V. (2012). Opportunity makes the thief. Really? And so what?. Crime Science, 1(3), 1-9. 7. https://doi.org/10.1186/2193-7680-1-3

${ }^{38}$ Article 5 Paragraph (1) Prosecutor's Regulation Indonesian Republic Number 15 of 2020 On The Cessation of Prosecutions based on Restorative Justice. 
2. A criminal act is only punishable by imprisonment of not more than 5 (five) years; and

3. A criminal offense is committed with the value of the evidence or the loss incurred as a result of the criminal act of not more than Rp. 2,500,000.00 (two million and five hundred thousand rupiah).

While the exception to terminating prosecution based on restorative justice in the PERJA for cases, among others: ${ }^{39}$

1. A crime against state security, the dignity of the President and Vice President, cooperation countries, heads of cooperation countries and their representatives, public order, and morals;

2. A criminal act which is punishable by a minimum criminal threat;

3. Narcotics crime;

4. Environmental crime; and

5. A criminal act committed by a corporation.

Peace efforts regulated in the PERJA are 40

1. The Public Prosecutor offers reconciliation efforts to victims and perpetrators.

2. Peace efforts as referred to in paragraph (1) shall be carried out without pressure, coercion, and intimidation.

3. As referred to in paragraph (2), reconciliation efforts shall be carried out at the prosecution stage, namely at the time of handing over responsibility for the suspect and evidence (stage two).

So after the victim and the perpetrator accepted the peace effort, the peace process was continued. After the effort is accepted, the public prosecutor makes a reconciliation effort report received to the Head of the District Attorney's Office or the Branch Head of the District Attorney's Office to be forwarded to the Head of the High Attorney's Office. ${ }^{41}$ The peace process is carried out voluntarily, with deliberation to reach a consensus, without pressure, coercion, and intimidation, then in the peace process, the public prosecutor acts as a facilitator. ${ }^{42}$ After the peace process was reached, the Victim and the Suspect made a written peace agreement in front of the Public Prosecutor. (2) The peace agreement, as referred to above, shall be in the form of: 43

1. Agree to make peace accompanied by the fulfillment of certain obligations; or

2. Agree to make peace without fulfilling certain obligations.

${ }^{39}$ Article 5 Paragraph (8) Prosecutor's Regulation Indonesian Republic Number 15 of 2020 concerning Cessation of Prosecutions based on Restorative Justice.

${ }^{40}$ Article 7 Prosecutor's Regulation Indonesian Republic Number 15 of 2020 concerning Cessation of Prosecutions based on Restorative Justice.

${ }^{41}$ Article 8 Paragraph (5) Prosecutor's Regulation Indonesian Republic Number 15 of 2020 concerning Cessation of Prosecutions based on Restorative Justice.

42 Article 9 Prosecutor's Regulation Indonesian Republic Number 15 of 2020 concerning Cessation of Prosecutions based on Restorative Justice.

${ }^{43}$ Article 10 Paragraph (2) Prosecutor's Regulation Indonesian Republic Number 15 of 2020 concerning Cessation of Prosecutions based on Restorative Justice. 
Article 14 states that: "In the event that a peace agreement is made at the stage of the investigation, it can be used as a consideration for the Public Prosecutor to stop prosecution based on Restorative Justice by fulfilling the terms and procedures for peace as regulated in this regulation. As for detention, suspension of detention and release of a criminal offense perpetrator is regulated in article 15:

1. Detention, suspension of detention, and/or delivery of detention of a perpetrator is carried out under the provisions of laws and regulations.

2. If the perpetrator is detained and the case is subject to termination of the prosecution based on Restorative Justice, the Public Prosecutor shall immediately release the suspect after the termination of prosecution is issued.

3. Release of a perpetrator as referred to in paragraph (2) an official report is made.

Thus, criminal cases can be resolved using a restorative justice approach, as regulated in the PERJA, so that the sense of justice in society can be fulfilled. Efforts to settle cases with PERJA Number 15 of 2020 are expected to be able to reduce the accumulation of court cases and are also expected to be able to reduce the number of overcapacity in social institutions, especially during the current Covid-19 pandemic outbreak.

Together with PERJA Number 15 of 2020, PERMA Number 4 of 2020 concerning Administration and Trial of Criminal Cases in Electronic Courts is also born, which further strengthens efforts to reduce the accumulation of cases in court and gives hope of achieving a simple, fast and low-cost judicial principle. Hopefully, with the establishment of these two (2) new regulations, it can provide a sense of justice and create a judicial process that is fast and low cost.

According to General Attorney, ST. Burhanuddin, that since the enactment of PERJA No. 15 of 2020, there have been more than 100 minor criminal cases throughout the work area of the attorney's office in Indonesia, which have been resolved restoratively using this PERJA. ${ }^{44}$ Until now, PERJA No. 15 of 2020 is still under the supervision of the Attorney's Office to minimize various possible deviations and abuse of authority. ${ }^{45}$ Supervision of this authority's implementation is carried out strictly and in stages by the Attorney General of the Republic of Indonesia to prosecutors in the field, considering that this great authority will undoubtedly open up transactional loopholes, abuse or corruption later. ${ }^{46}$

${ }^{44}$ Wicaksono, A. (2020, October 18). Jaksa Agung: 100 Kasus Lebih Diselesaikan Secara Restoratif. CNN Indonesia. Retrieved from https://www.cnnindonesia.com/nasional/20201018040400-12-559691/jaksaagung-100-kasus-lebih-diselesaikan-secara-restoratif

${ }^{45}$ Fathur Rochman. (2020, August 12). Jaksa Agung Perintahkan Jampidum Kawal Peraturan Kejaksaan 15/2020. Antara News. Retrieved from https://www.antaranews.com/berita/1664102/jaksa-agung-perintahkanjampidum-kawal-peraturan-kejaksaan-15-2020

${ }^{46}$ Hakim, Z. B. (2020, August 17). Opini:Terobosan Kejaksaan Ri Dalam Menggapai Keadilan Restroatif Serta Upaya Kedepannya. Persatuan Jaksa Indonesia. Retrieved from http://pii.kejaksaan.go.id/index.php/home/berita/1025 
As previously stated, the criminal cases that are often resolved through a restorative justice approach by prosecutors are juvenile delinquents. As a sub-system of the criminal justice system in handling juvenile delinquent cases, the Attorney General's Office has been trying to prioritize the interests and welfare of children, including by issuing several strategic policies related to its function in handling juvenile delinquents. It is by drafting the Attorney General's Regulation Number 006 of 2015 regarding Guidelines for the Implementation of Diversion at the Prosecution Level. It provides education and training to prosecutors who handle children, and implementing child handling programs is included in the Strategic Plan of the Republic of Indonesia Attorney's Office. ${ }^{47}$ However, some weaknesses can affect the juvenile criminal justice process, namely: 48

1. The enactment of the detention period for children is according to the Law on the Criminal Justice System for children who are 14 (fourteen) years old or more and suspected of a juvenile delinquent with the threat of imprisonment of 7 (seven) years or more.

2. There is no clear difference regarding the Special Guidance Institutions for Children and Child Penitentiaries.

3. Transitional Period Reform of Children's Institutions, the Law on the Juvenile Criminal Justice System requires a transitional period of 5 years.

4. Limited existence of Community Officers.

Even though there are weaknesses in restorative justice, there are also advantages to this concept: the community has been given space to handle their legal problems that are felt to be fairer based on low cost and fast track. Besides, the burden on the state is reduced to deal with criminal acts that can still be resolved independently by the community and the burden of providing a budget for the administration of the criminal justice system in terms of the administration of correctional institutions is reduced. ${ }^{49}$

\section{CONCLUSION}

The formal justice process in Indonesia tends to accumulate cases so that the concept of restorative justice emerges in resolving criminal cases that occur in Indonesia. Law enforcement based on the concept of restorative justice in Indonesia continues to develop and has been used in several criminal cases such as traffic accidents, fraud cases, and child crime cases. Law enforcement based on the concept of restorative justice requires all law enforcement agencies in Indonesia, one of which is the Attorney General's Office.

\footnotetext{
${ }^{47}$ Kristyanto, G. H. (2018). Op. Cit.

${ }^{48}$ Sari, Junita. (2018). Implementasi Restorative Justice Dalam Penyelesaiantindak Pidana Bullying yang Dilakukan Anak (Studi Putusan NO. 5/Pid.Sus-Anak/2017/PN Bnj). Jurnal Sumatera Utara, pp. 1-29, p. 20 49 Ibid., p. 19
} 
Settlement of criminal cases by the Attorney's Office uses the Indonesian Attorney's Office Regulation (PERJA) Number 15 of 2020 concerning Cessation of Prosecution Based on Restorative Justice. This settlement is carried out through the settlement of cases outside the court. The application of settlement of cases outside the court is taken to make the settlement of cases more effective, especially during the increasing Covid-19 pandemic. It can also reduce the accumulation of cases. One of the criminal cases that are often resolved through a restorative justice approach by the attorney's office is a juvenile delinquent case.

In this study, the authors suggest that it is necessary to expand the scope of the Attorney's Office Regulation Number 15 of 2020 and reaffirm its socialization to law enforcement officers, police, prosecutors, judges, advocates, the community, especially at the regional level. So that the implementation of the forms of action resolution can be understood in a simple, fast, and keep justice.

\section{REFERENCES}

Amdani, Y. (2016). Konsep Restorative Justice dalam Penyelesaian Perkara Tindak Pidana Pencurian oleh Anak Berbasis Hukum Islam dan Adat Aceh. AL-'ADALAH, 13(1), pp. 61-76, https://doi.org/10.24042/adalah.v13i1.1130

Angkasa, Hanadi, Saryono, Muhammad Budi Setyadi. (2009). Model Peradilan Restoratif Dalam Sistem Peradilan Anak (Kajian tentang Praktik Mediasi Pelaku dan Korban dalam Proses Peradilan Anak di Wilayah Hukum Balai Pemasyarakatan Purwokerto). Jurnal Dinamika Hukum, 9(3), pp. 186-204, https://dx.doi.org/10.20884/1.jdh.2009.9.3.230

Anwar, M. (2020). Asimilasi dan Peningkatan Kriminalitas Di Tengah Pembatasan Sosial Berskala Besar Pandemi Corona. ADALAH: Buletin Hukum dan Keadilan, 4(1), pp. 101-106, https://doi.org/10.15408/adalah.v4i1.15504

Apriyanto, E. (2016). Penerapan Restorative Justice Sebagai Bentuk Diskresi Kepolisian Dalam Penyelesaian Perkara Tindak Pidana Penipuan di Polrestabes $\begin{array}{llll}\text { Semarang. Jurnal Spektrum Hukum, 13(1), pp. } & \text { 55-72 }\end{array}$ http://dx.doi.org/10.35973/sh.v13i1.1139

Ariefianto, Y. (2016). Penerapan Restoratif Justice Dalam Penyelesaian Kasus Kecelakaan Lalu Lintas. Kumpulan Jurnal Mahasiswa Fakultas Hukum. 1(1), pp. 1-26.

Arief; Hanafi, Ningrum Ambarsari. (2018). Penerapan Prinsip Restorative Justice Dalam Sistem Peradilan Pidana Di Indonesia. Al'Adl, 10(2), pp. 173-190, http://dx.doi.org/10.31602/al-adl.v10i2.1362

Biroli, A. (2015). Problematika Penegakan Hukum Di Indonesia (Kajian Dengan Perspektif Sosiologi Hukum). Dimensi Journal of Sociology, 8 (2), pp. 1-9. 
Clarke, R. V. (2012). Opportunity makes the thief. Really? And so what?. Crime Science, 1(3), 1-9, https://doi.org/10.1186/2193-7680-1-3

Firdaus, A. (2018-July). The Criminal Responsibility on the Under Age Children Exploitation in Indonesia [Proceedings of the 1st International Conference on Indonesian Legal Studies (ICILS 2018)]. Advances in Social Science, Education and Humanities Research, volume 192, Atlantis Press. pp, 79-82. https://doi.org/10.2991/icils-18.2018.15

Hakim, L. (2019). Implementasi Teori Dualistis Hukum Pidana Di Dalam Rancangan Kitab Undang-Undang Hukum Pidana (RKUHP). Jurnal Krtha Bhayangkara, 13(1), pp. 119, https://doi.org/10.31599/krtha.v13i1.12

Hakim, Z. B. (2020, August 17). Opini:Terobosan Kejaksaan Ri Dalam Menggapai Keadilan Restroatif Serta Upaya Kedepannya. Persatuan Jaksa Indonesia. Retrieved from http://pji.kejaksaan.go.id/index.php/home/berita/1025

Hartono, B. (2016). Analisis Keadilan Restoratif (Restorative Justice) Dalam Konteks Ultimum Remedium Sebagai Penyelesaian Permasalahan Tindak Pidana Anak. Pranata Hukum, 10 (2), pp. 86-98.

Harve, R., Marlina, M., Ekaputra, M., \& Ikhsan, E. (2016). Penerapan Diversi pada Tingkat Penuntut Umum terhadap Anak sebagai Pelaku Tindak Pidana Menurut UU No 11 Tahun 2012 (Studi Kasus di Cabang Kejaksaan Negeri Padangsidimpuan di Sibuhuan). USU Law Journal, 4(3), 198-207.

Hattu, J. (2020). Pertanggungjawaban Pidana Pengambilan Jenasah Covid-19 Secara Paksa Berdasarkan Aturan Tindak Pidana Umum dan Tindak Pidana Khusus. Jurnal Belo, 6(1), pp. 11-32.

Ishaq, A. R. (2019). Sanksi Penganiayaan Dalam Hukum Pidana Adat Kerinci dan Hukum Pidana Indonesia. Al-Risalah Forum Kajian Hukum dan Sosial Kemasyarakatan, 19(1), pp. 17-36, https://doi.org/10.30631/al-risalah.v19i1.147

Kristian, C. T. (2015). Penyelesaian Perkara Pidana Dengan Konsep Keadilan Restoratif (Restorative Justice) Dalam Sistem Peradilan Pidana Terpadu Di Indonesia. Jurnal Mimbar Justitia, 1 (2), pp. 592-607, https://doi.org/10.35194/ihmj.v1i2.42

Kristyanto, G. H. (2018). Fungsi Kejaksaan Dalam Mewujudkan Restorative Justice Dalam Penanganan Anak Berhadapan Dengan Hukum Di Indonesia. Jurnal Surya Kencana Dua: Dinamika Masalah Hukum dan Keadilan, 5(1), pp. 459-481. http://dx.doi.org/10.32493/SKD.v5i1.y2018.1543

Kurnia, P, et.al. (2015). Penegakan Hukum Melalui Restorative Justice Yang Ideal Sebagai Upaya Perlindungan Saksi Dan Korban. GEMA, 27(49), pp. 1497-1508.

Laksana, A. W. (2017). "Keadilan Restoratif Dalam Penyelesaian Perkara Anak Yang Berhadapan Dengan Hukum Dalam Sistem Peradilan Pidana Anak", Jurnal Pembaharuan Hukum, 4(1), pp. 57-64, 58, http://dx.doi.org/10.26532/jph.v4i1.1644 
Lazuardi, G. (2020). Pendekatan Restorative Justice Dalam Tindak Pelaku Penyebaran Hoaks. Jurnal Kertha Semaya, 8 (9), pp. 1301-1312, https://doi.org/10.24843/KS.2020.v08.i09.p01

Maramis, F. (2013). Hukum Pidana Umum dan Tertulis di Indonesia. Jakarta: Raja Grafindo Persada.

Marzuki, P. M. (2008). Penelitian Hukum. Cet2. Jakarta: Kencana.

Millah, I. A. (2020). Penanggulangan Kejahatan Di Masa Pandemi Covid-19 (Dalam Perspektif Kriminologi Dan Viktimologi). Jurnal Komunikasi Hukum (JKH), 6 (2), pp. 497513, https://dx.doi.org/10.23887/jkh.v6i2.28099

Muladi. (2005). Hak Asasi Manusia: Hakekat, Konsep dan Implikasinya Dalam Perspektif Hukum dan Masyarakat, Bandung: Refika Aditama.

Mukhlis, R. (2012). Tindak Pidana Di Bidang Pertanahan Di Kota Pekanbaru. Jurnal IImu Hukum, 4(1), 203-204.

Nurwianti, A. G., Wahyuningsih, S. E. (2017). Implementasi Restoratif/ Restorative Justice Dalam Penyelesaian Tindak Pidana Kecelakaan Lalu Lintas yang Dilakukan Oleh Anak di Polres Rembang. Jurnal Hukum Khaira Ummah, 12 (4), pp. 705-716.

Prayitno, K. (2012). Restorative Justice Untuk Peradilan di Indonesia (Perspektif Yuridis Filosofis dalam Penegakan Hukum In Concreto). Jurnal Dinamika Hukum, 12 (3), 407-420, http://dx.doi.org/10.20884/1.jdh.2012.12.3.116

Patricia Erickson (2003). Critical justice consciousness: Social injustice and the Criminal Justice System, Contemporary Justice Review, 6(4), 341-346, https://doi.org/10.1080/1028258032000144785

Rochman, F. (2020, August 12). Jaksa Agung Perintahkan Jampidum Kawal Peraturan Kejaksaan 15/2020. Antara News. Retrieved from https://www.antaranews.com/berita/1664102/jaksa-agung-perintahkan-jampidum-kawalperaturan-kejaksaan-15-2020

Rosita, D. (2018). Kedudukan Kejaksaan Sebagai Pelaksana Kekuasaan Negara Di Bidang Penuntutan Dalam Struktur Ketatanegaraan Indonesia. Ius Constituendum. 3(1), pp. 27-47, http://dx.doi.org/10.26623/iic.v3i1.862

Sari, J. (2018). Implementasi Restorative Justice Dalam Penyelesaiantindak Pidana Bullying yang Dilakukan Anak (Studi Putusan NO. 5/Pid.Sus-Anak/2017/PN Bnj). Jurnal Sumatera Utara, pp. 1-29.

Saputra, R. P. (2019). Perkembangan Tindak Pidana Pencurian Di Indonesia. Jurnal Pahlawan Volume. 2(2), pp. 1-8.

Saraswati, P. S. (2015). Fungsi Pidana Dalam Menanggulangi Kejahatan. Jurnal Advokasi, 5 (2), pp. 139-154. 
Sholahudin, U. (2018). Keadilan Hukum Bagi Si Miskin; Sebuah Elegi Si Miskin Dihadapan Tirani Hukum. Journal of Urban Sociology, 1 (1), pp. 35-45, https://doi.org/10.30742/jus.v1i1.562

Sriwidodo, J. (2014). Penerapan Mediasi Tindak Pidana Kekerasan Dalam Rumah Tangga Berdasarkan Restorative Justice Dalam Sistem Peradilan Pidana di Indonesia. Yogyakarta: Kepel Press.

Siregar, R. E. (2015). Due Process Of Law Dalam Sistem Peradilan Pidana Di Indonesia Kaitannya Dengan Perlindungan HAM. FITRAH, 1 (1), pp. 35-46, https://doi.org/10.24952/fitrah.v1i1.326

Sutiyoso, B. (2006). Penyelesaian Sengketa Bisnis, Solusi Dan Antisipasi Bagi Peminat Bisnis Dalam Menghadapi Sengketa Kini dan Mendatang. Yogyakarta: Citra Media.

Satria, H. (2018). Restorative Justice: Paradigma Baru Peradilan Pidana. Jurnal Media Hukum, 25(1), pp. 111-123, 117, https://doi.org/10.18196/jmh.2018.0107.111-123

Taufiq, M. (2013). Penyelesaian Perkara Pidana Yang Berkeadilan Substansial. Yustisia, 2(1), pp. 25-32, https://doi.org/10.20961/yustisia.v2i1.11058

Wagiu, J. D. (2015). Tinjauan Yuridis Terhadap Asas Keadilan Restoratif dalam Perkara Tindak Pidana Penggelapan. Lex Crimen, 4(1). pp. 57-70.

Wicaksono, A. (2020, October 18). Jaksa Agung: 100 Kasus Lebih Diselesaikan Secara Restoratif. CNN Indonesia. Retrieved from https://www.cnnindonesia.com/nasional/20201018040400-12-559691/jaksa-agung-100kasus-lebih-diselesaikan-secara-restoratif 